\title{
New species and new records of lichenicolous fungi from South Korea
}

\author{
Joshi $\mathrm{Y}^{1 *}$, Kondratyuk $\mathrm{S}^{2}$, Lőkös $\mathrm{L}^{3}$, Halda $\mathrm{JP}^{4}$, Oh S-O $\mathrm{O}^{5}$ and Hur $\mathrm{J}^{5} \mathrm{~S}^{5}$ \\ ${ }^{1}$ Lichenology laboratory, Department of Botany, S.S.J. Campus, Kumaun University, Almora - 263601, Uttarakhand, \\ Indiadryogeshcalo@gmail.com \\ ${ }^{2}$ M. H. Kholodny Institute of Botany, Tereshchenkivska str. 2, 01601 Kiev, Ukraine \\ ${ }^{3}$ Department of Botany, Hungarian Natural History Museum, H-1476 Budapest, Pf. 222, Hungary \\ ${ }^{4}$ Muzeum a galerie Orlických hor, Jiráskova 2, 51601 Rychnov n. Kn., Czech Republic \\ ${ }^{5}$ Korean Lichen Research Institute, Sunchon National University, Suncheon 540-950, South Korea
}

Joshi Y, Kondratyuk S, Lőkös L, Halda JP, Oh S-O, Hur J-S 2015 - New species and new records of lichenicolous fungi from South Korea. Mycosphere 6(4), 493-500, Doi 10.5943/mycosphere/6/4/11

\begin{abstract}
One new species of lichenicolous fungus (Endococcus xanthoparmeliae) along with four new records (Cercidospora caudata, Clypeococcum cladonema, Epicladonia simplex and Lichenostigma cosmopolites) are described based on floristic work on lichens and lichenicolous fungi in the Bogil, Chuja and Jeju Islands of South Korea, bringing the total number of lichenicolous fungi species recognized in South Korea to nineteen. The new species grows on the epilithic foliose lichen Xanthoparmelia coreana, while Cercidospora caudata, Clypeococcum cladonema, Epicladonia simplex and Lichenostigma cosmopolites grow on Caloplaca bogilana, Xanthoparmelia coreana, Cladonia sp. and Xanthoparmelia coreana, respectively. The new species is described in detail and compared with the morphologically most similar species of the genus, while brief description and ecology is being provided for the new records. Furthermore, presence of Endococcus verrucosus in South Korea is also being confirmed and a brief description of that too is also provided.
\end{abstract}

Key words - Flora - island - Lichens - Lichenicolous fungi - mycobiota

\section{Introduction}

Lichenicolous fungi have received increasing attention within the last decades and the number of known species is growing considerably (Etayo \& Breuss 1998, Lawrey \& Diederich 2003, 2011). However, the distribution of these fungi in South Korea is poorly known. Since the publication of checklist of lichens of South Korea (Hur et al. 2005), numerous species have been added to the lichen biota of the country, including some new to science (e.g. Y. Joshi et al. 2010abc, Lü et al. 2011, Moon 2011, Y. Joshi et al. 2011, Moon et al. 2012, Kondratyuk et al. 2013ab, S. Joshi et al. 2013, Y. Joshi \& Hur 2013ab), but very few work have been done on lichenicolous fungi. The first contribution regarding lichenicolous fungi of South Korea came from Thor et al. (2008), when they reported Sphinctrina leucopoda Nyl. colonizing Pertusaria sp. Later Y. Joshi et al. (2010a) added one more species for the lichenicolous flora of South Korea Dactylospora glaucomarioides (Tuck.) Hafellner parasitizing Ochrolechia sp., but the most remarkable contribution on the lichenicolous flora of South Korea came from Kondratyuk et al. 
(2013a), who published 12 species, including 3 new to science, and mentioned many other yet unidentified specimens that mostly appear to represent additional, undescribed taxa.

In the course of examining collections of lichenicolous fungi collected during lichenological research in Bogil, Chuja and Jeju Islands of South Korea in June 2011, 2012 and 2014, the authors recognized 4 new species for the country (Cercidospora caudata Kernst., Clypeococcum cladonema (Wedd.) D. Hawksw., Epicladonia simplex D. Hawksw. and Lichenostigma cosmopolites Hafellner \& Calat.) and 1 species new to science (Endococcus xanthoparmeliae), thus raising the number of lichenicolous fungi to 19 (Table 1). Besides this, presence of Endococcus verrucosus Hafellner in South Korea is also being confirmed. This paper provides information on the taxonomy, occurrence and ecology of the new species and new records of lichenicolous fungi in South Korea.

\section{Materials \& Methods}

All species of lichenicolous fungi were recorded from Bogil, Chuja and Jeju Islands of South Korea. The specimens were examined and deposited at Korean Lichen Research Institute, Sunchon National University (KoLRI). Macroscopical characters were studied using a Motic SMZ168 stereomicroscope, while microscopical characters were studied in hand sections mounted in water, using Olympus BX-50 compound microscope. The anatomical features were investigated by preparing sections of thalli and ascomata, and mounting them in water and $10 \% \mathrm{KOH}$. Only free ascospores lying outside the asci were measured. Images of anatomical and morphological characters were taken by HD-Measure LTHS-300 (Leetech Co., Seoul, South Korea) microscope connected to computer.

\section{Results and Discussion}

Cercidospora caudata Kernst., Verh. zool.-bot. Ges., Wien 44: 212 (1895).

Pseudothecia globose, immersed in the host thallus. Ascomatal wall colorless in its lower part and intensely greenish blue around the ostiole. Paraphysoids abundant. Asci 6-8 spored. Ascospores hyaline, narrowly ellipsoid or fusiform, 1-2-septate, 17-21 $\times 4-5 \mu \mathrm{m}$, strongly heteropolar, both cells very different in shape and size, the lower cell curved and attenuated as a tail. Pycnidia not seen. (For detailed description and illustrations see Kernstock 1894, Hafellner 1987).

Known distribution - It is a widely distributed species known from arid and Mediterranean regions to boreal and arctic regions and is mostly parasymbiont on different species of Teloschistaceae (Navarro-Rosinés et al. 2004).

Materials examined - SOUTH KOREA, Jeju-do province, Jeju-si, Hangyeong-myeon,

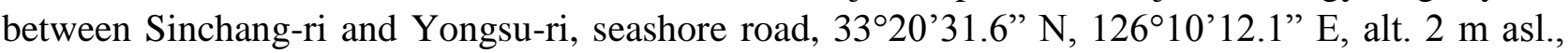
on rock, on thalli of Caloplaca bogilana, 18 June 2014, S.-O. Oh and party, 140120, 140168, 140187 (KoLRI 022416, 022299, respectively); ibid., 18 June 2014, L. Gagarina, 140170-1 (KoLRI 022417); Chuja-do island, Chuja-myeon, Sinyang-1-ri, seashore of Mojini-mongdol, $33^{\circ} 56^{\prime} 44.9^{\prime \prime} \mathrm{N}, 126^{\circ} 20^{\prime} 03.0^{\prime \prime} \mathrm{E}$, alt. $2 \mathrm{~m}$ asl., on rock, on thalli of Caloplaca bogilana, 21 June 2014, L. Gagarina, 140863, 140864-2, 140871, 140872 (KoLRI 022418, 022419, 022420, 022421, respectively).

Clypeococcum cladonema (Wedd.) D. Hawksw., Bot. J. Linn. Soc. 75: 197 (1977).

Ascomata pseudothecia, black, globose, ostiolate, numerous (6-12) and united in groups by a common clypeus, immersed; clypeus forming a rounded, black and raised patch on the surface of the host lichen to 1-2 mm diam.; pseudothecial walls brown to dark brown pigmented; hymenium I-, K/I-. Asci 8-spored. Ascospores 1-septate, olivaceous brown to brown, (15-) 17-20 × (6-) 7-8 $\mu \mathrm{m}$, with a thin perispore. Conidia hyaline, simple, bacilliform, (4-) 4.5-5 $\times 0.8-1 \mu \mathrm{m}$. (For detailed description and illustrations see Hawksworth 1977). 

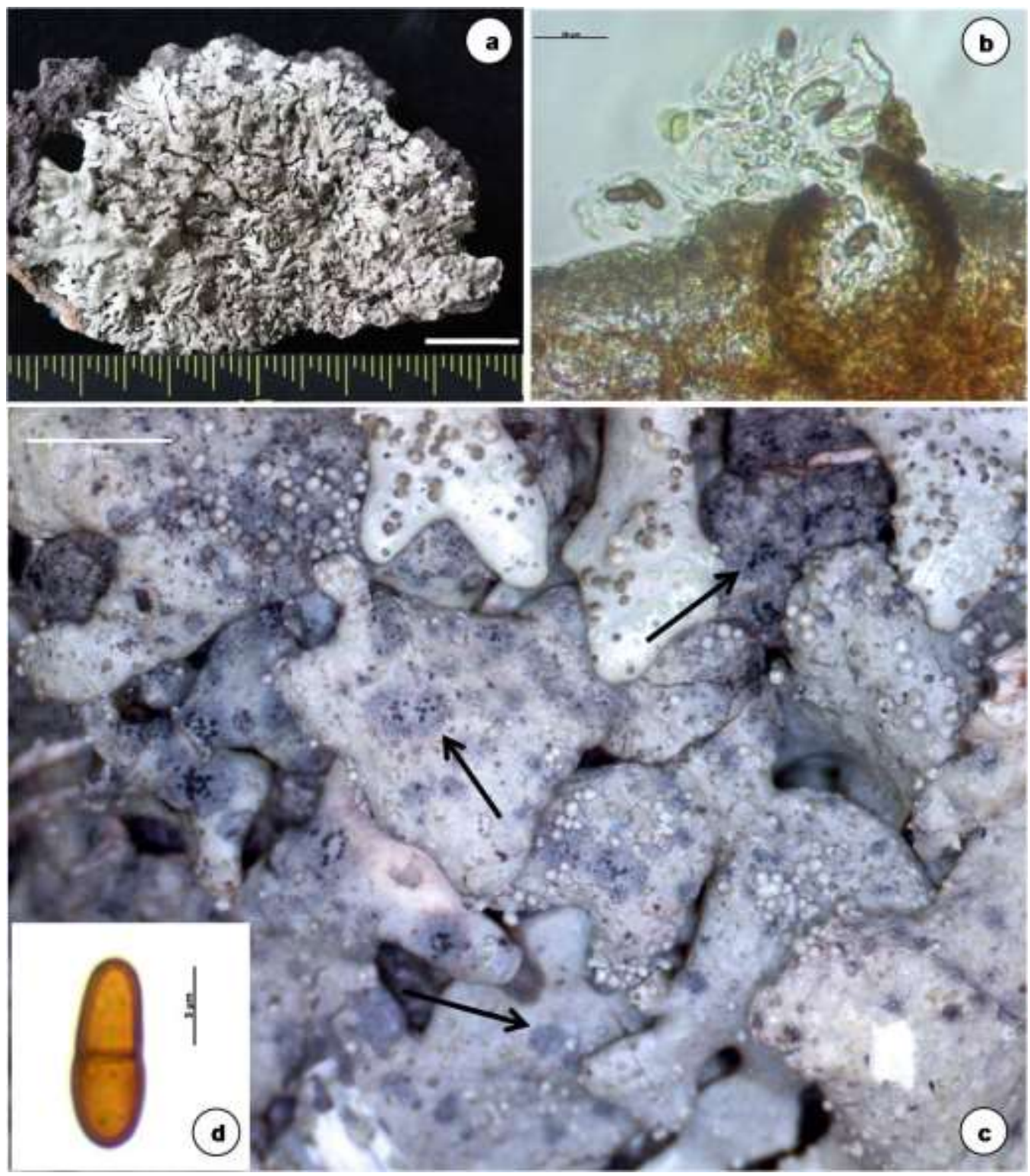

Fig. 1 - a: Thallus of Xanthoparmelia coreana, b: Cross section of perithecia, c: Magnified view of Xanthoparmelia coreana thallus infected by Endococcus xanthoparmeliae (arrows indicating the infected portions), d: Inset image of spore. Scale Bars: a $10 \mathrm{~mm}$; b $20 \mu \mathrm{m}$; c $3 \mathrm{~mm}$; d $5 \mu \mathrm{m}$.

Known distribution - The species is reported from Western Europe, Macaronesia and has it extensions up to Antarctic. It is new for South Korea and is found colonizing thallus of Xanthoparmelia coreana.

Materials examined - SOUTH KOREA, Jeju-do province, Jeju-si, Hangyeong-myeon, between Sinchang-ri and Yongsu-ri, seashore road, 33 20'31.6" N, 126 10'12.08" E, alt. 2 m, on rocks, on Xanthoparmelia thalli, 18 June 2014, S.-O. Oh \& party 140210, 140235 (KoLRI 021321, 021330).

Endococcus verrucosus Hafellner, Herzogia 10: 8 (1994).

Pseudothecia black, globose, immersed in the host thallus. Ascomatal wall colorless in its lower part and brown around the ostiole. Paraphysoids absent. Periphyses septate. Asci 8-spored. Ascospores pale brown to brown, ellipsoid to broadly fusiform, 1-septate, 12.5-15 × 7-8 $\mu \mathrm{m}$, spore wall thick and smooth. Pycnidia not seen. (For detailed description and illustrations see Hafellner 1994). 
Known distribution - In South Korea, the species is growing on the thallus and apothecia of Aspicilia sp. Previously, Kondratyuk et al. (2013a) reported Endococcus cf. verrucosus from Sinuido Island of South Korea colonizing gray crustose thallus (probably Aspicilia). At that time they were not quite sure whether it was Endococcus verrucosus, since the ascospores were quite small and the host was also not identified. In the present study, we found a fertile specimen of Aspicilia which is heavily infected by Endococcus sp., which on its examination revealed to be $E$. verrucosus, thus confirming its presence and range extension in South Korea. The species was previously reported from Europe and North America (Kainz \& Triebel 2004).

Material examined - SOUTH KOREA, Jeollanam province, Shinan Co., Bogil Island, $34^{\circ} 07^{\prime} 30.7^{\prime \prime} \mathrm{N}, 126^{\circ} 31^{\prime} 15.1$ ” E, alt. $2 \mathrm{~m}$ asl., on rock, on thalli of Aspicilia sp., 23 June 2011, X. Y. Wang and J. A. Ryu, 110685 (KoLRI 013713).

Endococcus xanthoparmeliae Y. Joshi, S.Y. Kondr., L. Lőkös \& Hur, sp. nov. MYCOBANK No.: MB 814049

(Fig 1a-d)

Type: South Korea, Jeju-do province, Jeju-si, Hangyeong-myeon, between Sinchang-ri and Yongsu-ri, seashore road, $33^{\circ} 20^{\prime} 31.6^{\prime \prime} \mathrm{N}, 126^{\circ} 10^{\prime} 12.1^{\prime \prime} \mathrm{E}$, alt. $2 \mathrm{~m}$ asl., on rock, on thalli of Xanthoparmelia coreana, 18 June 2014, S.-O. Oh and party, Holotype KoLRI 021331, Isotype KoLRI 021325.

Etymology: The species epithet refers to the host name, i.e. lichen genus Xanthoparmelia (Vain.) Hale.

Similar to Endococcus parmeliarum but differs in having longer and wider ascospores and different host.

Thallus absent, non-lichenized, lichenicolous on Xanthoparmelia coreana (Fig. 1a), forming regularly rounded grayish to dark gray spots to $(0.2-) 0.3-0.4 \mathrm{~mm}$ diam. with (1-) 4-7 (11) perithecia (Fig. 1c), but often forming much larger patches to 1-2 (3) cm or covering the whole host thalline lobe.

Ascomata perithecioid, immersed or semi-immersed into host thallus, 45-55(-60) $\mu \mathrm{m}$ diam. and to $60 \mu \mathrm{m}$ high, brownish hyphae of parasite can be seen as brown layer below host thalline cortex. Exciple wall dark brown to $6(-8) \mu \mathrm{m}$ thick in the upper portion, and to $4-5 \mu \mathrm{m}$ thick in the lower half, (3-) 5-6 (-8) $\times 1-1.5(-2) \mu \mathrm{m}$ (Fig. 1b). Paraphyses absent. Asci clavate, 8spored, 22-26 × 10-12 $\mu \mathrm{m}$. Ascospores dark brown, 2-celled, oblong to ovoid, both cells almost the same, (8-) 10-12 × 4-5 (-6) $\mu \mathrm{m}$ (Fig. 1d).

Conidiomata not seen.

Distribution and host: The species is so far known only from two localities in South Korea - i.e. Jeju and Chuja Islands, where it is growing luxuriantly on the thallus of Xanthoparmelia coreana, which was often damaged by Clypeococcum cladonema and Lichenostigma cosmopolites.

Taxonomic notes: Endococcus xanthoparmeliae is similar to E. parmeliarum Etayo in Etayo \& Sancho, described from Chile colonizing Parmelia saxatilis, but differs in having longer and wider ascospores [(8-) 10-12 × 4-5 (-6) $\mu \mathrm{m}$ vs. 6.5-9.5 $\times 3-3.8 \mu \mathrm{m})]$ and different host (Etayo and Sancho 2008). Endococcus propinquus (Körb.) D. Hawksw. and E. exerrans Nyl. are other species having similar spore length and often confused with the new species. E. propinquus has a much wider host preference and wider spores $(6.5-7 \mu \mathrm{m})$, while $E$. exerrans has narrower spores $(3-4 \mu \mathrm{m})$ and is confined to Rhizocarpon sp. E. verrucosus Hafellner, another known species of the genus in South Korea, differs from the new species in having bigger and wider spores $(12.5-15 \times 7-8 \mu \mathrm{m})$ and different host (Aspicilia).

In brownish coloration of the spores, Endococcus xanthoparmeliae is sometimes mistaken with Sphaerellothecium parmeliae Etayo, which however differs from the new taxon in having smaller and narrower spores $(8.5-10 \times 3-4 \mu \mathrm{m})$, different hosts [Parmelia saxatilis (L.) Ach. and $P$. sulcata Taylor] and presence of large black stroma-like necrotic surfaces on host thallus from which arises parasitic ascomata (Etayo \& Diederich 1998). 
Table 1 List of so far known lichenicolous fungi colonizing various lichens in South Korea.

\begin{tabular}{|c|c|c|c|}
\hline $\begin{array}{l}\text { S. } \\
\text { No. }\end{array}$ & Lichenicolous fungi & Host & Reference (s) \\
\hline 1. & Abrothallus microspermus Tul. & Parmotrema reticulatum & $\begin{array}{l}\text { Kondratyuk et al. } \\
\text { (2013a) }\end{array}$ \\
\hline 2. & Arthonia epiphyscia Nyl. & $\begin{array}{l}\text { Hyperphyscia sp., Phaeophyscia } \\
\text { orbicularis }\end{array}$ & $\begin{array}{l}\text { Kondratyuk et al. } \\
\text { (2013a) }\end{array}$ \\
\hline 3. & Cercidospora caudata Kernst. & Caloplaca bogilana & this paper \\
\hline 4. & $\begin{array}{l}\text { Clypeococcum cladonema (Wedd.) D. } \\
\text { Hawksw. }\end{array}$ & Xanthoparmelia coreana & this paper \\
\hline 5. & $\begin{array}{l}\text { Dactylospora glaucomarioides } \quad \text { (Tuck.) } \\
\text { Hafellner }\end{array}$ & Ochrolechia sp. & Joshi et al. (2010a) \\
\hline 6. & Endococcus verrucosus Hafellner & Aspicilia sp. & $\begin{array}{l}\text { Kondratyuk et al. } \\
\text { (2013a); this paper }\end{array}$ \\
\hline 7. & $\begin{array}{l}\text { Endococcus xanthoparmeliae Y. Joshi, S.Y. } \\
\text { Kondr., L. Lökös \& Hur }\end{array}$ & Xanthoparmelia coreana & this paper \\
\hline 8. & Epicladonia simplex D. Hawksw. & Cladonia sp. & this paper \\
\hline 9. & $\begin{array}{l}\text { Lichenochora obscuroides (Linds.) Triebel \& } \\
\text { Rambold }\end{array}$ & $\begin{array}{l}\text { Phaeophyscia adiastola, } \\
\text { exornatula, } P \text {. hispidula }\end{array}$ & $\begin{array}{l}\text { Kondratyuk et al. } \\
\text { (2013a) }\end{array}$ \\
\hline 10. & $\begin{array}{l}\text { Lichenodiplis lecanorae (Vouaux) Duko \& D. } \\
\text { Hawksw. }\end{array}$ & Lecanora sp. & $\begin{array}{l}\text { Kondratyuk et al. } \\
\text { (2013a) }\end{array}$ \\
\hline 11. & Lichenostigma cosmopolites Hafellner \& Calat. & Xanthoparmelia coreana & this paper \\
\hline 12. & $\begin{array}{l}\text { Lichenostigma heterodermiae S.Y. Kondr., L. } \\
\text { Lőkös \& J.S. Hur }\end{array}$ & $\begin{array}{l}\text { Heterodermia diademata, } H . \\
\text { dissecta, H. hypoleuca, H. japonica, } \\
\text { H. microphylla }\end{array}$ & $\begin{array}{l}\text { Kondratyuk et al. } \\
\text { (2013a) }\end{array}$ \\
\hline 13. & Opegrapha phaeophysciae R. Sant. & $\begin{array}{l}\text { Phaeophyscia adiastola, } \\
\text { exornatula, } P . \text { aff. Squarrosa }\end{array}$ & $\begin{array}{l}\text { Kondratyuk et al. } \\
\text { (2013a) }\end{array}$ \\
\hline 14. & $\begin{array}{l}\text { Phoma heterodermiae S.Y. Kondr., L. Lőkös } \\
\text { \& J.-S. Hur }\end{array}$ & Heterodermia hypoleuca & $\begin{array}{l}\text { Kondratyuk et al. } \\
\text { (2013a) }\end{array}$ \\
\hline 15. & $\begin{array}{l}\text { Roselliniopsis phaeophysciae S.Y. Kondr., L. } \\
\text { Lőkös \& J. S. Hur }\end{array}$ & $\begin{array}{l}\text { Phaeophyscia adiastola, } P . \quad \text { cf. } \\
\text { exornatula, } P . \text { cf. limbata }\end{array}$ & $\begin{array}{l}\text { Kondratyuk et al. } \\
\text { (2013a) }\end{array}$ \\
\hline 16. & Sphinctrina leucopoda Nyl. & Pertusaria sp. & Thor et al. (2008) \\
\hline 17. & Sphinctrina tubaeformis A. Massal. & Pertusaria sp. & $\begin{array}{l}\text { Kondratyuk et al. } \\
\text { (2013a) }\end{array}$ \\
\hline 18. & Stigmidium fuscatae (Arnold) R. Sant. & Acarospora subg. Phaeothallia & $\begin{array}{l}\text { Kondratyuk et al. } \\
\text { (2013a) }\end{array}$ \\
\hline 19. & Taeniolella phaeophysciae D. Hawksw. & $\begin{array}{l}\text { Phaeophyscia } \quad \text { adiastola, } \\
\text { exornatula, } \quad P . \quad \text { limbata, } \\
\text { orbicularis, P. rubropulchra }\end{array}$ & $\begin{array}{l}\text { Kondratyuk et al. } \\
(2013 a)\end{array}$ \\
\hline
\end{tabular}

Materials examined - SOUTH KOREA, Jeju-do province, Jeju-si, Hallim-eup, Gwideok-ri, coast near the Chorok village, $33^{\circ} 26^{\prime} 33.3^{\prime \prime} \mathrm{N}, 126^{\circ} 17^{\prime} 00.1^{\prime \prime} \mathrm{E}$, alt. $02 \mathrm{~m}$ asl., on rock, on thalli of Xanthoparmelia coreana growing together with Diploschistes euganeus, 05 July 2012, S. Kondratyuk and party, 121368 (KoLRI 016425 sub Diploschistes euganeus); Jeju-do province, Jeju-si, Hangyeong-myeon, between Sinchang-ri and Yongsu-ri, seashore road, 33²0’31.6" N, $126^{\circ} 10^{\prime} 12.1$ " E, alt. $2 \mathrm{~m}$ asl., on rock, on thalli of Xanthoparmelia coreana damaged by Lichenostigma and Endococcus, 18 June 2014, S.-O. Oh and party, 140215, 140217, 140223, 140226, 140233 (KoLRI 021323, 021324, 021326, 021328, 021329, respectively); ibid., on thalli of Xanthoparmelia coreana damaged by Clypeococcum, 18 June 2014, S.-O. Oh and party, 140210 (KoLRI 021321); ibid., on thalli of Xanthoparmelia coreana damaged by Clypeococcum and Lichenostigma, 18 June 2014, Y. Joshi and party, 140168, 140187 (KoLRI 022299, 022300, respectively); ibid., on thalli of Xanthoparmelia coreana damaged by Endococcus, 18 June 2014, Y. Joshi and party, 140216, 140221 (KoLRI 022412, 022301, respectively); ibid., on rock, on thalli of Xanthoparmelia coreana, 18 June 2014, S. Kondratyuk and L. Lőkös, 140265 (KoLRI 022422); Jeju-do province, Jeju-si, Seogwipo-si, Pyoseon-myeon, Pyoseon-ri, seashore rocks, 33 19'23.25" $\mathrm{N}, 126^{\circ} 50^{\prime} 48.45^{\prime}$ E, alt. $2 \mathrm{~m}$ asl., on thalli of Xanthoparmelia coreana damaged by Endococcus growing together with Pyxine endochrysina, 19 June 2014, Y. Joshi and party, 140495, 140517 
(KoLRI 022302, 022413, respectively); Chuja-do island, Yecho-ri, Mt. Dondae, 33²4'40.7' N, $126^{\circ} 29^{\prime} 35.9$ " E, alt. $661 \mathrm{~m}$ asl., on thalli of Xanthoparmelia coreana damaged by Endococcus, 21 June 2014, Y. Joshi and party, 140761, 140762 (KoLRI 022414, 022415, respectively).

Epicladonia simplex D. Hawksw., Bull. Br. Mus. Nat. Hist. 9: 19 (1981).

Conidiomata pycnidia, usually on galls formed on squamules of Cladonia sp., galls convex. Pycnidia immersed at first, but superficial at maturity, scattered, dark brown, subglobose to cupuliform, 100-150 $\mu \mathrm{m}$ diam. Pycnidial wall light olivaceous green to brown. Conidiogenous cells holoblastic. Conidia arising singly, rounded at the apex and truncated at the base, simple, nonseptate, 10.5-13 × 2-3 $\mu \mathrm{m}$ diam. (For detailed description and illustrations see Hawksworth 1981).

Known distribution - It is probably a parasymbiont growing on Cladonia sp. and is being reported from Denmark (Alstrup 1994), Finland (Hawksworth 1981, Santesson et al. 2004), Sweden (Ihlen \& Wedin 2006), North America (Esslinger \& Egan 1995) and Russia (Zhurbenko 2004). The present study extends its distribution in Asia.

Material examined - SOUTH KOREA, Jeju-do province, Jeju-si, Nohyeong-dong, near Cheonwang Temple, 33²4'39.4" N, 126²9'38.1" E, $681 \mathrm{~m}$ asl., on Pinus bark, on thalli of Cladonia sp., 18 June 2014, S. Kondratyuk and L. Lőkös, 140662-2 (KoLRI 022422).

Lichenostigma cosmopolites Hafellner \& Calat., Mycotaxon 72: 108 (1999).

Hyphal strands superficial, dark brown, spreading over the host thallus, septate, ramified to net-like. Ascomata dark brown to black, scattered, subglobose. Centrum I+ orange-red, K/I+ blue. Asci 8-spored. Ascospores hyaline, 1-septate, narrowly obovate, halonate, 8-10 × 3-5 $\mu \mathrm{m}$. Pycnidia not seen. (For detailed descriptions and illustrations see Hafellner \& Calatayud 1999).

Known distribution - It is a widely distributed lichenicolous fungus known from all the continents except Antarctica colonizing Xanthoparmelia species (Calatayud et al. 2004).

Materials examined - SOUTH KOREA, Jeju-do province, Jeju-si, Hangyeong-myeon, between Sinchang-ri and Yongsu-ri, seashore road, 33²0’31.6” N, 126 ${ }^{\circ} 10^{\prime} 12.1^{\prime \prime}$ E, alt. $2 \mathrm{~m}$ asl., on rock, on thalli of Xanthoparmelia coreana damaged also by Endococcus xanthoparmeliae, 18 June 2014, S.-O. Oh and party, 140215, 140223, 140226, 140233 (KoLRI 021323, 021326, 021328, 021329, respectively); ibid, on thalli of Xanthoparmelia coreana damaged also by Clypeococcum, 18 June 2014, S.-O. Oh and party, 140168, 140187 (KoLRI 022299, 022300, respectively).

\section{Acknowledgements}

We are grateful to Dr. Edit Farkas (Vácrátót, Hungary) for her generous help with some literature on lichenicolous fungi, and to Dr. Ludmila Gagarina (St. Petersburg, Russia), Dr. Anna S. Kondratiuk and Jung Shin Park (Suncheon, South Korea) for their help in the field work. YJ, SK, LL and JPH are thankful to Prof. J.-S. Hur for his cordial hospitality in South Korea, and Dr. S.-O. Oh for organizing 2014 excursion to Jeju and Chuja Islands. This work was supported by Korean Forest Service Program (KNA 2014) through Korea National Arboretum, a grant from the Korean National Research Resource Center Program (NRF-2014M3A9B8002115), and (for LL) partly by the Hungarian Scientific Research Fund (OTKA K81232).

\section{References}

Alstrup V. 1994 - A lichen excursion to Bornholm 1993. Graphis Scripta 6, 49-55.

Calatayud V, Hafellner J, Navarro-Rosinés P. 2004 - Lichenostigma Hafellner (1983). In: Lichen Flora of the Greater Sonoran Desert Region. Vol. 2. (eds TH Nash III, BD Ryan, P Diederich, C Gried, F Bungartz). Lichens Unlimited, Arizona State University, Tempe, Arizona, pp. 664-669.

Esslinger TL, Egan RS. 1995 - A sixth checklist of the lichen-forming, lichenicolous, and allied fungi of the continental United States and Canada. Bryologist 98, 467-549; doi: 
org/10.2307/3243586.

Etayo J, Breuss O. - 1998 New species and interesting records of lichenicolous fungi. Österr Z Pilzk 7, 203-213.

Etayo J, Diederich P. - 1998 Lichenicolous fungi from the western Pyrenees, France and Spain. IV. Ascomycetes. Lichenologist 30(2), 103-120; doi.org/10.1017/S0024282992000112.

Etayo J, Sancho LG. - 2008 Hongos Liquenicolas del Sur de Sudamerica, especialmente de Isla Navarino (Chile). Bibliotheca Lichenologica 98, 1-302.

Hafellner J. - 1987 Studien über lichenicole Pilze und Flechten VI. Ein verändertes Gattungskonzept für Cercidospora. Herzogia 7, 355-365.

Hafellner J. - 1994 Beiträge zu einem Prodromus der lichenicolen Pilze Österreichs und angrenzender Gebiete. I. Über einige neue und seltene Arten. Herzogia 10, 1-28.

Hafellner J, Calatayud V. - 1999 Lichenostigma cosmopolites, a common lichenicolous fungus on Xanthoparmelia species. Mycotaxon 72, 107-114.

Hawksworth DL. - 1977 Three new genera of lichenicolous fungi. Botanical Journal of the Linnaean Society 75, 195-209.

Hawksworth DL. - 1981 The lichenicolous Coelomycetes. Bulletin of the British Museum (Natural History), Botany 9, 1-198.

Hur JS, Koh YJ, Harada H. - 2005. A checklist of Korean lichens. Lichenology 4, 65-95.

Ihlen PG, Wedin M. - 2006 Notes on two lichenicolous fungi on Cladonia botrytes in Scandinavia. Graphis Scripta 18, 38-40.

Joshi S, Koh YJ, Lőkös L, Jayalal U, Hur JS. - 2013 Graphis koreana (Graphidaceae, Ostropales), a new species from South Korea. Lichenologist 45, 593-597; doi.org/10.1017/S0024282913000224.

Joshi Y, Hur JS. - 2013a Endocarpon maritima sp. nov. (lichenized Ascomycota) from the maritime region of South Korea. Mycotaxon 123, 163-167; doi.org/10.5248/123.163.

Joshi Y, Hur JS. 2013b - Endocarpon subramulosum (Verrucariaceae) a new species of lichenized fungi from South Korea. Mycobiology 41(4), 243-244; doi.org/10.5941/MYCO.2013.41.4.243.

Joshi Y, Knudsen K, Wang XY, Hur JS. - 2010a Dactylospora glaucomarioides (Ascomycetes, Dactylosporaceae): a lichenicolous fungus new to South Korea. Mycobiology 38(4), 321322; doi.org/10.4489/MYCO.2010.38.4.321.

Joshi Y, Lücking R, Yamamoto Y, Wang XY, Koh YJ, Hur JS. - 2010b A new species of Graphis (lichenized Ascomycetes) from South Korea. Mycotaxon 113, 305-309; doi.org/10.5248/113.305.

Joshi Y, Vondrák J, Vondráková O, Nguyen TT, Hur JS. - 2011 Caloplaca allochroa (lichenized Ascomycetes), a new saxicolous lichen species from South Korea. Mycotaxon 117, 261267; doi.org/10.5248/117.261.

Joshi Y, Wang XY, Yamamoto Y, Koh YJ, Hur JS. - 2010c A first modern contribution to Caloplaca biodiversity in South Korea: two new species and some new country records. Lichenologist 42, 715-722; doi.org/10.1017/S0024282910000368.

Kainz C, Triebel D. - 2004 Endococcus Nyl. (1855). In: Lichen Flora of the Greater Sonoran Desert Region. Vol. 2. (eds TH Nash III, BD Ryan, P Diederich, C Gried, F Bungartz). Lichens Unlimited, Arizona State University, Tempe, Arizona, pp. 648-651.

Kernstock E. - 1894 Lichenologische Beiträge. Verhandlungen der Zoologisch-Botanischen Gesellschaft in Wien 44, 191-224.

Kondratyuk S, Lőkös L, Tschabanenko S, Haji Moniri M, Farkas E, Wang XY, Oh S-O, Hur J-S. 2013a New and noteworthy lichen forming fungi and lichenicolous fungi. Acta Botanica Hungarica 55, 275-349; doi.org/10.1556/ABot.55.2013.3-4.9.

Kondratyuk S, Lőkös L, Zarei-Darki B, Haji Moniri M, Tschabanenko S, Galanina I, Yakovchenko L, Hooshmand F, Ezhkin AK, Hur J-S. - 2013b Five new Caloplaca species (Teloschistaceae, Ascomycota) from Asia. Acta Botanica Hungarica 55, 41-60; doi.org/10.1556/ABot.55.2013.1-2.4. 
Lawrey JD, Diederich P. - 2003 Lichenicolous fungi: interactions, evolution and biodiversity. Bryologist 106(1), 80-120; doi.org/10.1639/0007-2745(2003)106[0080:LFIEAB]2.0.CO;2.

Lawrey JD, Diederich P. 2011 - Lichenicolous fungi - worldwide checklist, including isolated cultures and sequences available. http://www.lichenicolous.net (accessed 27 Jan 2012).

Lü L, Joshi Y, Elix JA, Lumbsch HT, Wang HY, Koh YJ, Hur JS. - 2011 New and noteworthy species of the lichen genus Lecanora (Ascomycota; Lecanoraceae) from South Korea. Lichenologist 43(3), 321-329; doi.org/10.1017/S0024282911000144.

Moon KH. - 2011 Species of the genus Menegazzia (Parmeliaceae, Lecanorales) in Korea. Journal of Japanese Botany 86, 324-326.

Moon KH, Nakanishi M, Kashiwadani H. - 2012 New or noteworthy species of Graphidaceae (Ostropales, Ascomycota) in Korea. Journal of Japanese Botany 87, 320-325.

Navarro-Rosinés P, Calatayud V, Hafellner J. - 2004 Cercidospora Körb. (1865). In: Lichen Flora of the Greater Sonoran Desert Region. Vol. 2. (eds TH Nash III, BD Ryan, P Diederich, C Gried, F Bungartz). Lichens Unlimited, Arizona State University, Tempe, Arizona, pp. 635-639.

Santesson R, Moberg R, Nordin A, Tønsberg T, Vitikainen O. - 2004 Lichen-forming and lichenicolous fungi of Fennoscandia. Museum of Evolution, Uppsala University.

Thor G, Moon KH, Tibell L. - 2008 New findings of calicioid lichens and fungi in Korea. Journal of Japanese Botany 83, 256-260.

Zhurbenko MK. - 2004 Lichenicolous and some interesting lichenized fungi from the northern Ural, Komi Republic of Russia. Herzogia 17, 77-86. 